\title{
Examining the economic benefits of agritourism: The case of New Jersey
}

\author{
Brian J. Schilling ${ }^{a}$ \\ Department of Agricultural, Food \& Resource Economics and Rutgers Cooperative Extension, \\ Rutgers University \\ Kevin P. Sullivan ${ }^{\text {b }}$ \\ New Jersey Agricultural Experiment Station, Rutgers University \\ Stephen J. Komar ${ }^{c}$ \\ Department of Agricultural and Resource Management Agents, Rutgers Cooperative Extension \\ of Sussex County
}

\begin{abstract}
Submitted 7 March 2012 / Revised 3 May and 22 June 2012 / Accepted 16 July 2012 / Published online 21 November 2012
Citation: Schilling, B. J., Sullivan, K. P., \& Komar, S. J. (2012). Examining the economic benefits of agritourism:

The case of New Jersey. Journal of Agriculture, Food Systems, and Community Development, 3(1), 199-214.

http://dx.doi.org/10.5304/jafscd.2012.031.011

Copyright (C) 2012 by New Leaf Associates, Inc.
\end{abstract}

\section{Abstract}

Many small American farms struggle to remain economically viable due to a confluence of global

a Department of Agricultural, Food \& Resource Economics and Rutgers Cooperative Extension, Rutgers University; Cook Office Building, 55 Dudley Road; New Brunswick, New Jersey 08901 USA; schilling@njaes.rutgers.edu

b New Jersey Agricultural Experiment Station, Rutgers University; Administrative Services Building III, 3 Rutgers Plaza; New Brunswick, New Jersey 08901 USA; sullivan@njaes.rutgers.edu

c Department of Agricultural and Resource Management Agents, Rutgers Cooperative Extension of Sussex County, Rutgers University; 129 Morris Turnpike; Newton, New Jersey 07860 USA; skomar@njaes.rutgers.edu

Corresponding author: Brian J. Schilling, Assistant Extension Specialist, Department of Agricultural, Food and Resource Economics, Rutgers, The State University of New Jersey; 55 Dudley Road, Cook Office Building, Room 108; New Brunswick, New Jersey 08901 USA; +1-848-932-9127; schilling@njaes.rutgers.edu market dynamics, rising costs, and urbanization pressure. Agritourism is an increasingly popular form of alternative agriculture enterprise development designed to expand farm income, generally through fuller employment of existing farm resources. The economic significance of agritourism within the farm community, however, is not well understood. Existing literature is inconclusive about the importance of agritourism as a component of farm income. This paper examines the economic benefits of agritourism, using data from a statewide economic impact assessment in New Jersey. Results show broad

Note: Funding for this project was provided by the New Jersey Department of Agriculture, Rutgers Cooperative Extension, and Rutgers Food Policy Institute. A Rutgers Cooperative Extension fact sheet has been published that summarizes descriptive highlights from this research (see http://njaes. rutgers.edu/pubs/publication.asp?pid=E333). Portions of this paper have been the subject of presentations made to the New Jersey Department of Agriculture and farm organizations. 
variability across farm scales in terms of the relative reliance on agritourism as a source of farm revenue. A significant percentage of farms hosting agritourism were found to earn no immediate income from such activities, suggesting that some farmers may be motivated by either nonmonetary or deferred economic benefits from hosting agritourism.

\section{Keywords}

agritourism, deferred economic benefits, economic impact, multifunctionality, nonmonetary benefits

\section{Introduction}

Many small family farms in the United States struggle to remain economically viable in the face of changing global markets, urbanization pressures, structural changes in the food retailing system, and the perpetual vagaries of weather, diseases, and pests. Confronted with declining profitability, operators of small farms commonly face the options of exiting agriculture, expanding off-farm employment to supplement household earnings, or developing alternative agricultural enterprises (McGehee, 2007; Ollenburg \& Buckley, 2007). Agritourism has emerged as one form of alternative enterprise development for a growing number of farmers. Agritourism provides opportunity to increase farm income and diversify product lines, while simultaneously educating the nonfarm public about farming and enhancing community engagement (Busby \& Rendle, 2000; Che, Veeck \& Veeck, 2005; Ilbery, Bowler, Clark, Crockett \& Shaw, 1998; McGehee \& Kim, 2004; Mitchell \& Turner, 2010; Nickerson, Black \& McCool, 2001; Ollenburg \& Buckley, 2007; Tew \& Barbieri, 2012).

While several authors point to its long history in Europe (Busby \& Rendle, 2000; Hill \& Busby, 2002; Sharpley \& Vass, 2006), agritourism is a relatively new addition to agricultural economic development and policy discourse in the United States. While it is receiving a surge of attention among farmers and scholars, there is presently no standard definition of agritourism, nor is there consensus on the types of activities that constitute agritourism (Carpio, Wohlgenant \& Boonsaeng, 2008; Fleischer \& Tchetchik, 2005; McGehee \& Kim, 2004; Nickerson et al., 2001; Phillip, Hunter
\& Blackstock, 2010; Schilling, Marxen, Heinrich \& Brooks, 2006; Tew \& Barbieri, 2012; Veeck, Che \& Veeck, 2006). More than a decade ago, Busby and Rendle (2000) identified 13 definitions of agritourism in the literature. Nomenclature intended to reflect the practice of creating farm visitations for educational or recreational purposes is similarly variable, encompassing a range of terms including farm tourism, agritourism, agritainment, agricultural tourism, and rural tourism (Mitchell \& Turner, 2010; Phillip et al., 2010).

Defined in the current context as the business of establishing farms as travel destinations for educational and recreational purposes, agritourism encompasses a variety of on-farm activities, including direct marketing (e.g., farm markets and pickyour-own operations), educational activities (e.g., school tours and winery tours), entertainment (e.g., corn mazes and hayrides), outdoor recreation (e.g., hunting and fishing), and accommodations (e.g., bed and breakfasts) (Schilling et al., 2006; Schilling, Sullivan \& Marxen, 2007). These activities have attracted the nonfarm public to farms in impressive numbers. Barry and Hellerstein (2004) estimate that 62 million American adults visited a farm at least once between 2000 and 2001.

Beyond noting definitional challenges, over the past two decades various authors have commented on the lack of a coherent and comprehensive body of literature on agritourism development and its impact on farm operations (Busby \& Rendle, 2000; Opperman, 1995; Tew \& Barbieri, 2012). The characterization and perceptions of agritourism operators (Barbieri \& Mshenga, 2008; Sharpley \& Vass, 2006; Tew \& Barbieri, 2012), gender roles in agritourism (McGehee, Kim \& Jennings, 2007; Nilsson, 2002), and farmer motivations for developing agritourism enterprises (McGehee \& Kim, 2004; Nickerson et al., 2001; Ollenburg \& Buckley, 2007) are areas of inquiry that have received more focused research consideration in recent years. Income generation and diversification potential has been found to be a primary motivation for agritourism development on farms (see, for example, McGehee \& Kim, 2004; Schilling et al., 2006); however, some studies have found, perhaps paradoxically, that agritourism income tends to be relatively insubstantial in relation to 
total farm income (Busby \& Rendle, 2000; Hjalager, 1996; Oppermann, 1995; Sharpley \& Vass, 2006).

Tew and Barbieri (2012) therefore deem the literature inconclusive in terms of the economic benefits of agritourism. The current dearth of information on the extent of U.S. farmer participation in agritourism and its economic rewards is attributed in large part to aforementioned inconsistencies in terminology and definitions, as well as related data deficiencies (Busby \& Rendle, 2000; Carpio et al., 2008; Oppermann, 1995; Phillip et al., 2010).

Tew and Barbieri (2012) point to the existence of nonmonetary benefits of agritourism, primarily in the context of farm family motivations for enterprise development, as another rationale for agritourism development. These include personal entrepreneurial or lifestyle goals, expansion of farm employment opportunities for family members, preservation of rural lifestyle, and social interaction with guests (see McGehee et al., 2007; Mitchell \& Turner, 2010). The education of the nonfarm public about agriculture has also been identified as an important impetus behind agritourism development (Alonso, 2010; Barbieri \& Mshenga, 2008).

Consideration of existing literature suggests the need for more targeted empirical research to clearly articulate the economic benefits of agritourism in the U.S., particularly at state or regional scales. Using New Jersey as a case study, this article presents a statewide agritourism assessment conducted to better understand the industry's revenue and its distribution across farms of different economic scales. First we examine drivers of industry growth and available statistics on the distribution of agritourism in the United States. Next we describe the framework for the empirical assessment and the implementation of a survey to a random sample of 1,500 New Jersey farmers. We then present and discuss study results on the magnitude of the economic benefits (revenues) realized by New Jersey farmers and differences in the reliance on agritourism across farm scales.

\section{Context for Agritourism Growth in the United States}

A convergence of supply- and demand-side factors contribute to the current popularity of agritourism in the U.S. and portend continued growth in this industry (Carpio et al., 2008). From an agricultural perspective, farmers face challenges to their sustained economic viability due to increasingly global competition in domestic and export markets, and ensuing price uncertainties (Dimitri, Effland \& Conklin, 2005). Farmers in many regions also face urbanization pressures that divert land from production agriculture, raise farmland prices, fragment the farmland base, and lead to less farm-friendly business environments (Berry, 1978; Lopez, Adelaja \& Andrews, 1988; Schilling, 2009). However, the urbanization of rural areas also brings potential opportunities for new alternative agricultural enterprises and market access. Agritourism is a particularly attractive economic growth and diversification strategy because it allows farmers to generate additional income from existing farm assets (land, labor, and machinery) that may be underutilized or idle for significant periods of time, moderates seasonal fluctuations in farm cash flow, and expands on-farm employment opportunities for family members (Barbieri, Mahoney \& Butler, 2008; Schilling et al., 2007; Tew \& Barbieri, 2012).

On the demand side, American consumers are expressing greater preference for local food purchasing options and reconnecting to an agrarian heritage from which most are now several generations removed (Alonso, 2010; Kortright \& Wakefield, 2011; Martinez, et al., 2010; Veeck et al., 2006). The term "locavore" has recently entered the common vernacular as many Americans shorten their food supply chains by patronizing farmers' markets, joining community supported agriculture enterprises, or expanding home gardening. These activities offer consumers the ability to rekindle their connection to food production, while blending recreational and educational experiences.

Support for the growth of agritourism also stems from its ancillary economic and nonmarket benefits. Although not well quantified in the literature, agritourism is often cited as a rural economic development strategy as it generates direct economic opportunities for other businesses within a local economy (Tew \& Barbieri, 2012). As a multifunctional resource, farmland supports 
production of various food, fiber, and other market-based goods and services. It also confers rural amenities and other positive externalities not fully valued in private markets (Abler, 2004; Batie, 2003; Hellerstein et al., 2002). Examples include exposure to agrarian culture, scenic views, ecosystem services (e.g., wildlife habitat, and air and water recharge areas), and outdoor recreation options. Properly developed agritourism operations provide an opportunity for the public to access these amenities, which are especially valued as a contrast to the undesired accompaniments to urbanization (e.g., congestion, noise, pollution, and the homogeneity of built landscapes). ${ }^{1}$

\section{Agritourism in the Northeastern United States} Carpio et al. (2008) summarize estimates of annual agritourism income in the U.S. that vary widely, from USD800 million to USD3 billion. The National Agricultural Statistics Service (NASS) began collecting information on "recreational services" under the section on "income from farmrelated sources" in the 2002 Census of Agriculture. Examples provided in the census form instructions included only hunting and fishing. In the 2007 census, the inquiry was expanded to include income from "agri-tourism and recreational services." Specific examples provided were farm or winery tours, hay rides, corn maze fees, hunting, and fishing. This expansion of the definition limits comparability of data between the two census periods.

The 2007 Census of Agriculture reports that 23,350 U.S. farms offer agritourism, earning USD566.8 million from these activities (USDANASS, 2009). The authors of this paper argue that NASS's agritourism statistics provide only a partial

\footnotetext{
${ }^{1}$ Ryan and Walker (2004) find that the dwindling open spaces and natural landscapes in more urban regions of the country are often under private ownership (see, also, Lindsey and Knaap, 1999). Farms are an increasingly important component of existing and planned trail or greenway networks. In New Jersey, for example, recent years have witnessed increased coordination between the state's open space and farmland preservation programs for the purpose of expanding and interconnecting greenways and stream corridors to fulfill environmental goals and provide nature recreation opportunities.
}

perspective on the extent of such activities in the U.S. farm sector due to the rather narrow definition employed. Significantly, in each of the last two censuses, the value of farm products sold through direct marketing was enumerated separately from agritourism and recreational services income. ${ }^{2}$ Further, the authors' experience with previous agritourism research (Schilling et al., 2006) suggests that farmers do not readily identify with the term "agritourism" and may not associate their agritourism activities with that label.

Despite these limits, the Census of Agriculture provides a useful perspective on the current geographic distribution of agritourism in the United States. The most recent census data show that a disproportionately high concentration of direct marketing and agritourism activity is centered in the northeastern region of the U.S. Whereas that region produces less than 5 percent of total national farm revenue, it accounts for more than one-quarter of farm direct marketing sales and nearly 14 percent of agritourism income (table 1). All nine northeastern states rank significantly higher in direct marketing sales as compared to their respective ranks based upon total farm sales. In all but three northeastern states (Maine, Rhode Island and Vermont), national rankings based on agritourism revenue are higher than their respective ranks by total farm sales.

The importance of direct marketing and agritourism in the Northeast is more starkly shown by the percentage of total farm income derived from these activities (table 2). In 2007, the shares of farm revenue derived from agritourism and direct marketing in the Northeast were 0.56 per-

\footnotetext{
${ }^{2}$ A more complete enumeration of the prevalence and magnitude of agritourism arguably could be achieved through summation of agritourism and direct marketing data collected in the Census of Agriculture. However, farm direct marketing statistics suffer, in the authors' opinion, from two deficiencies when viewed for such purposes. First, the data reflect only farm products sold "directly to individual consumers for human consumption" and exclude a range of ornamental products (for example, nursery stock, flowers, Christmas trees) that are significant components of agriculture in many states, particularly New Jersey. Second, the data include direct marketing income derived from the sale of farm products through off-farm venues (e.g., community farmers' markets), which are not included in most definitions of agritourism.
} 
Table 1. Agritourism and Direct Marketing Income in the Northeast: Ranks Among Coterminous States (2007)

\begin{tabular}{|c|c|c|c|c|c|c|}
\hline State & $\begin{array}{c}\text { Income from } \\
\text { Agritourism \& } \\
\text { Recreational Services } \\
\text { (USD1000) }\end{array}$ & $\begin{array}{l}\text { National } \\
\text { Rank }\end{array}$ & $\begin{array}{l}\text { Income from } \\
\text { Direct Marketing } \\
\text { of Farm Products } \\
\text { (USD1000) }\end{array}$ & $\begin{array}{l}\text { National } \\
\text { Rank }\end{array}$ & $\begin{array}{l}\text { Total Farm Sales } \\
\quad \text { (USD1000) }\end{array}$ & $\begin{array}{l}\text { National } \\
\text { Rank }\end{array}$ \\
\hline Connecticut & 8,582 & 18 & 29,752 & 13 & 551,553 & 44 \\
\hline Maine & 1,012 & 44 & 18,419 & 23 & 617,190 & 42 \\
\hline Massachusetts & 5,306 & 33 & 42,065 & 9 & 489,820 & 46 \\
\hline New Hampshire & 2,316 & 41 & 16,021 & 25 & 199,051 & 47 \\
\hline New Jersey & 24,700 & 4 & 30,106 & 12 & 986,885 & 40 \\
\hline New York & 17,985 & 7 & 77,464 & 2 & $4,418,634$ & 26 \\
\hline Pennsylvania & 14,926 & 11 & 75,893 & 3 & $5,808,803$ & 20 \\
\hline Rhode Island & 689 & 48 & 6,292 & 41 & 65,908 & 48 \\
\hline Vermont & 1,490 & 42 & 22,863 & 17 & 673,713 & 41 \\
\hline United States & 566,834 & & $1,211,268$ & & $297,220,489$ & \\
\hline Northeast & 77,006 & & 318,875 & & $13,811,557$ & \\
\hline $\begin{array}{l}\text { Northeast States as } \\
\% \text { of U.S. }\end{array}$ & $13.6 \%$ & & $26.3 \%$ & & $4.6 \%$ & \\
\hline
\end{tabular}

Source: USDA-NASS, 2007 Census of Agriculture.

cent and 2.31 percent, respectively. Comparable figures for the United States are 0.19 percent and 0.41 percent. Individually, the Northeast states

Table 2. Relative Reliance on Agritourism and Direct Marketing Income in the Northeast: Ranks Among Coterminous States (2007)

\begin{tabular}{|c|c|c|c|c|}
\hline State & $\begin{array}{l}\% \text { of Total Farm } \\
\text { Sales from } \\
\text { Agritourism \& } \\
\text { Recreational } \\
\text { Services }\end{array}$ & $\begin{array}{l}\text { National } \\
\text { Rank }\end{array}$ & $\begin{array}{c}\% \text { of Total } \\
\text { Farm Sales } \\
\text { from Direct } \\
\text { Marketing } \\
\text { of Farm } \\
\text { Products }\end{array}$ & $\begin{array}{c}\text { National } \\
\text { Rank }\end{array}$ \\
\hline Connecticut & 1.56 & 2 & 5.39 & 4 \\
\hline Maine & 0.16 & 24 & 2.98 & 7 \\
\hline Massachusetts & 1.08 & 5 & 8.59 & 2 \\
\hline New Hampshire & 1.16 & 4 & 8.05 & 3 \\
\hline New Jersey & 2.50 & 1 & 3.05 & 6 \\
\hline New York & 0.41 & 13 & 1.75 & 8 \\
\hline Pennsylvania & 0.26 & 17 & 1.31 & 9 \\
\hline Rhode Island & 1.05 & 6 & 9.55 & 1 \\
\hline Vermont & 0.22 & 20 & 3.39 & 5 \\
\hline United States & 0.19 & & 0.41 & \\
\hline Northeast & 0.56 & & 2.31 & \\
\hline
\end{tabular}

Source: USDA-NASS, 2007 Census of Agriculture. rank ahead of all other U.S. states in terms of the percentage of farm income derived from direct marketing. While relatively low, the proportion of income derived from agritourism and recreational activities also tends to be higher among northeastern states than in other regions of the U.S. New Jersey ranked first among the coterminous 48 states in the percentage of farm revenue generated from agritourism (2.5 percent).

\section{Evaluation Framework and Study Methods}

\section{Evaluation Framework}

The preceding review of existing research proffers that agritourism development can be beneficial to farmers, farm visitors, and communities. A broad categorization of these benefits is summarized in table 3. For farmers, an obvious benefit of agritourism is the potential for additional revenue. However, past research has uncovered other motives for offering agritourism, including entrepreneurism, expansion of family farm employment, and strong desires to maintain agrarian lifestyles (Nickerson et al., 2001; Ollenburg \& Buckley, 2007; Tew and Barbieri, 2012). Interview-based research 
Table 3. Benefits of Agritourism

\begin{tabular}{|c|c|c|}
\hline Farmers & Farm Visitors & Community \\
\hline $\begin{array}{l}\text { - Revenue enhancement and } \\
\text { diversification } \\
\text { - Public engagement and education } \\
\text { about agriculture } \\
\text { - Expansion of on-farm employment } \\
\text { opportunities for family members } \\
\text { - Fulfillment of entrepreneurial goals } \\
\text { - Maintenance of rural/agrarian } \\
\text { lifestyles }\end{array}$ & $\begin{array}{l}\text { - Exposure to rural amenities } \\
\text { - Recreation outlets } \\
\text { - Connection to food production } \\
\text { and agrarian culture } \\
\text { - Maintenance of local food } \\
\text { production }\end{array}$ & $\begin{array}{l}\text { - Economic development and } \\
\text { diversity/jobs/taxes } \\
\text { - Preservation of farm-based rural } \\
\text { amenities } \\
\text { - Management of disamenities of } \\
\text { nonagricultural development } \\
\text { - Retention of cultural and historic } \\
\text { values } \\
\text { - Defined sense of place/local identity }\end{array}$ \\
\hline
\end{tabular}

with New Jersey farmers also suggests a willingness to engage in agritourism without immediate financial gain due to a belief that public engagement pays dividends in the long term through, for example, the fostering of a more favorable political or local business climate (Schilling et al., 2006).

The demand-side (consumer) drivers of agritourism growth were previously summarized. As most Americans continue to drift farther away from their agricultural heritage, the novelty of reconnecting with rural lifestyles, experiencing farm amenities, engaging in farm-based recreational opportunities, and learning about food production is an attractive departure from a more urban existence. The significant value the American public places on farm-based amenities, many of which are public goods not appropriately valued in private markets, has been the subject of extensive research for more than two decades (see Bergstrom \& Ready (2011) or Hellerstein et al. (2002) for excellent reviews). The retention of farming through farmland preservation, differential taxation programs, legal (right-to-farm) protections, agricultural economic development initiatives, and other public interventions has been rationalized largely on the basis of food security, growth management, and the perpetuation of rural amenities (Hellerstein et al., 2002). If agritourism can make farms more economically viable and sustainable, it contributes positively to the advancement of these same public goals.

The last broadly defined beneficiary of agritourism is the community to which the activity is linked. Many authors note the economic multiplier effects of agritourism, namely the impact on other local businesses, local employment, and tax revenues. ${ }^{3}$ The preservation of rural amenities, as well as historic and cultural values, also contributes to the desirability of a community to potential residents and businesses by creating a sense of place (Adelaja, Hailu, Wyckoff \& Bailey, 2008). Through its contribution to farm retention, agritourism similarly helps communities manage or limit disamenities that may be associated with uncontrolled development (e.g., congestion, pollution, loss of scenic viewscapes).

\section{Study Methods}

Our study objective is to measure total statewide agritourism revenue earned by farmers in New Jersey, a state in which census of agriculture data suggest such activities are occurring to a significant extent. The study population was defined as all New Jersey farms. A random sample of 1,500 New Jersey farm operations, stratified by sales class, was selected from the National Agricultural Statistics Service list frame of farms active in the beginning of the 2007 calendar year. The decision to survey the general farming population served to avoid the difficulties of drawing a random sample from a poorly defined population of farms with agritourism. ${ }^{4}$ This approach allowed the study team to

\footnotetext{
${ }^{3}$ Das and Rainey (2010), based on their assessment of agritourism impacts in Arkansas, question the job-generation impacts of agritourism due to the industry's reliance on family labor.

${ }^{4}$ Veeck et al. (2006) note the challenge of making generalizations about a given population of agritourism operations because of the diversity of operations encompassed, but also due to the lack of firm population characteristics necessary for drawing a representative, random sample. In the context of their study in Michigan, they state "no determination can be made of exactly how many family farms engage in agritourism
} 
establish the prevalence of agritourism within the New Jersey farming community and have the statistical power needed to make an informed estimate of its direct economic contributions to the farm economy.

The questionnaire was developed jointly by the study team and NASS staff members and was modeled after agritourism economic impact assessments conducted by NASS in Vermont in 2000 and 2002 (New England Agricultural Statistics Service, 2004). The survey comprised nine substantive questions. Six were open-ended questions (acreage of the farm operation and revenues earned in each of five categories of agritourism activity), two questions contained categorical responses (the percentage of farm income earned from agritourism and farm sales class), and one question had a dichotomous response scale (was the farm engaged in agritourism?). All questions directed respondents to focus on the 2006 production year.

The survey defined agritourism broadly as the business of establishing farms as travel destinations for educational and recreational purposes, consistent with policy language promulgated by the New Jersey Department of Agriculture and previous statewide research by Schilling et al. (2006). Five broad types of agritourism activity were defined:

- On-farm direct-to-consumer sales of agricultural products (e.g., pick-your own, U-cut Christmas trees, on-farm markets);

- Educational tourism (e.g., school tours, winery tours, farm work experiences);

- Entertainment (e.g., hay rides, corn mazes, petting zoos, haunted barns);

- Accommodations (e.g., birthday parties, picnicking, bed and breakfasts); and

- Outdoor recreation (e.g., horseback riding, hunting, fishing, hiking, bird watching).

activities" (p. 241). Admittedly their study predated the release of the 2007 Census of Agriculture, which for the first time collected data on agritourism. But for the reasons previously stated in this paper, the authors maintain that census data do not reflect fully the population of agritourism operators, thereby resulting in a continued lack of certainty when developing sampling frames.
The exclusion of off-farm agriculturally themed venues (for example, community farmers' markets, county farm fairs, and living history farms) was predicated on the increasingly prevalent position in the academic literature that agritourism is defined by its link to a working farm (Phillip et al., 2010; Barbieri \& Mahoney, 2009).

The questionnaire was mailed to the random sample of farms by the New Jersey Field Office of the National Agricultural Statistics Service between April and July 2007. A modified Dillman method was employed. Data collection consisted of two survey mailings and telephone follow-up prompts (Dillman, 2007). A total of 1,043 completed surveys were returned, yielding a response rate of 69.5 percent. The relatively high response rate for a survey soliciting information on farm financial characteristics is attributed to NASS's credibility within the farming community and the agency's safeguards to ensure the confidentiality and anonymity of survey participants.

Descriptive statistical analysis was conducted in SAS to evaluate the distribution of agritourism activity across size classes within the sample of farms participating in the study. Chi-square tests of independence were used to evaluate associations among categorical data. Inferences to the population of New Jersey farms (e.g., total industry wide agritourism revenue) were made through use of expansion factors. ${ }^{5}$

\section{Results}

\section{Prevalence and Distribution of Agritourism Activity Across Farm Sizes}

Descriptive analysis revealed that 21 percent of New Jersey farms offer some form of agritourism in 2006 (table 4). Participation in agritourism activities was found to vary across farm sizes, as defined by sales volume. For ease of presentation, results are summarized for two size classes of farms: (1) farms earning at least USD250,000 in

\footnotetext{
${ }^{5}$ Expansion factors were derived for each stratum by dividing the strata population sizes by strata sample sizes. These expansion factors were developed in conjunction with NASS so that the summation of expanded data for all sampling units is the direct expansion estimate of the population.
} 
Table 4. Involvement in Agritourism by Farm Sales Class (2006 Data, New Jersey)

\begin{tabular}{lcr}
\hline $\begin{array}{l}\text { Farm Size } \\
\text { (Gross farm sales) }\end{array}$ & $\begin{array}{c}\text { Percent of } \\
\text { Farms Reporting } \\
\text { Agritourism }\end{array}$ & $\begin{array}{r}\text { No. of NJ Farms in } \\
\text { Sales Class }\end{array}$ \\
\hline All Farms & $\mathbf{2 1 . 5}$ & $\mathbf{1 0 , 3 2 7}$ \\
More than USD250,000 & 38.0 & 686 \\
Less than USD250,000 & 20.4 & 9,641 \\
USD100,000 to USD249,999 & 21.7 & 923 \\
USD50,000 to USD99,999 & 25.5 & 462 \\
USD10,000 to USD49,999 & 28.7 & 1,764 \\
< USD10,000 & 17.0 & 6,954 \\
\hline
\end{tabular}

a Source: USDA-NASS (2009). farms suggests its importance within the economic heart of the state's farming industry.

Statewide agritourism revenue was estimated to be USD57.52 million in 2006. As a point of reference, reported farm sales in New Jersey totaled USD986.9 million in 2007 (USDA-NASS, 2009). Agritourism revenue was split nearly evenly between farms earning at least USD250,000 in farm income and those earning less (table 5). Agritourism revenue averaged USD17,870 ( $\mathrm{n}=153, \mathrm{SD}=\mathrm{USD} 53,992)$ for small agritourism farms; the 95 percent confidence interval is [USD9,246, USD26,494].

Table 5. Reliance on Agritourism as a Source of Farm Income, by Farm Sales Class, New Jersey

\begin{tabular}{|c|c|c|c|c|c|c|c|}
\hline \multirow{2}{*}{$\begin{array}{l}\text { Farm Size } \\
\text { (Gross Sales) }\end{array}$} & \multirow{2}{*}{$\begin{array}{l}\text { No. of Farms } \\
\text { in Sample }\end{array}$} & \multicolumn{4}{|c|}{ Pct. of Farm Income from Agritourisma,b } & \multirow{2}{*}{$\begin{array}{l}\text { Avg. Agritourism } \\
\text { Revenue } \\
\text { per Farm }{ }^{\mathrm{a}, \mathrm{c}}\end{array}$} & \multirow{2}{*}{$\begin{array}{c}\text { Estimated } \\
\text { Total NJ } \\
\text { Agritourism Revenue }\end{array}$} \\
\hline & & $0 \%$ & $1-49 \%$ & $50-99 \%$ & $100 \%$ & & \\
\hline $\begin{array}{l}<\text { USD250,000 } \\
\text { (Small farms) }\end{array}$ & 189 & $17 \%$ & $25 \%$ & $17 \%$ & $40 \%$ & USD17,870 & USD28.47 million \\
\hline $\begin{array}{l}\text { USD250,000+ } \\
\text { (Large farms) }\end{array}$ & 25 & $32 \%$ & $60 \%$ & $0 \%$ & $8 \%$ & USD191,607 & USD29.05 million \\
\hline All Farms & 214 & $19 \%$ & $29 \%$ & $15 \%$ & $36 \%$ & USD33,382 & USD57.53 million \\
\hline
\end{tabular}

a Frequencies and means are based on a sample of 214 New Jersey farms reporting some form of agritourism.

b Percentages may not add to $100 \%$ due to rounding error.

${ }^{c}$ Means are calculated only for farms reporting revenue from agritourism.

annual sales (defined by the USDA as "large scale" farms and referred to in this paper as "large farms") and (2) farms earning less than USD250,000 (defined by the USDA and referred to in this paper as "small farms"). ${ }^{6}$

Large farms were 1.7 times more likely (38 percent compared to 20 percent) to report hosting agritourism than small farms. A Chi-square test of independence confirms that this difference is significant at the 5 percent level $\left(\chi^{2}=8.82, \mathrm{df}=1\right.$, $p=.003)$. This finding is noteworthy since farms in the USD250,000+ sales class account for less than 7 percent of New Jersey farms, but generate 84 percent of the state's total farm industry revenue. The prevalence of agritourism in this size class of

${ }^{6}$ Small farms reporting agritourism activities are herein referred to as "small agritourism farms." Large farms reporting agritourism are referred to as "large agritourism farms."
For large agritourism farms, mean agritourism revenue was USD191,607 (SD = USD224,348); however, the small sample size $(n=15)$ resulted in a wide 95 percent confidence interval [USD67,366, USD315,847].

Reliance on agritourism income (measured as a percentage of total farm income) differed markedly across farm sizes. Small agritourism farms were 5 times more likely ( 40 percent versus 8 percent) to earn all of their farm income from agritourism activities than large agritourism farms $\left(\chi^{2}=9.89, \mathrm{df}\right.$ $=1, p=.002)$. Similarly, small agritourism farms were 7.2 times more likely ( 57 percent versus 8 percent) to report deriving at least 50 percent of their total farm income from agritourism than large agritourism farms $\left(\chi^{2}=21.82, \mathrm{df}=1, p<0.001\right)$. 
Journal of Agriculture, Food Systems, and Community Development

ISSN: 2152-0801 online

www.AgDevJournal.com

Table 6. New Jersey Agritourism Revenue, by Type of Activity (2006)

\begin{tabular}{lccc}
\hline Type of agritourism activity & $\begin{array}{c}\text { Percent of farms with } \\
\text { agritourism revenue } \\
\text { that offer activity }\end{array}$ & $\begin{array}{c}\text { Statewide revenue } \\
\text { (USD millions) }\end{array}$ & $\begin{array}{c}\text { Percent of total } \\
\text { agritourism revenue }\end{array}$ \\
\hline On-farm sales of agricultural products & $92.3 \%$ & 40.54 & $70.5 \%$ \\
\hline Outdoor recreation & $11.9 \%$ & 9.19 & $16.0 \%$ \\
\hline Entertainment & $6.5 \%$ & 5.42 & $9.4 \%$ \\
\hline Educational tourism & $7.1 \%$ & 1.88 & $3.3 \%$ \\
\hline Accommodations & $3.6 \%$ & 0.50 & $0.9 \%$ \\
\hline Total & N/A & 57.53 & $100.0 \%$ \\
\hline
\end{tabular}

\section{Sources of Agritourism Revenue}

Table 6 decomposes estimated agritourism revenue by activity. The most common activity reported by New Jersey operators is on-farm direct marketing, which was offered by 92 percent of agritourism operators and accounted for 70 percent of all agritourism revenue. Farm retail markets, pick-yourown produce operations, U-cut Christmas tree farms, and community supported agriculture enterprises are examples of common farm direct marketing businesses.

The authors acknowledge that there is no consensus on the inclusion of direct marketing as a subset of agritourism. Its inclusion in this assessment is based on the view that on-farm direct markets are experiential, often comprising educational and recreational elements. While consensus is also lacking on an exact definition of "local," there is little ambiguity over the growing consumer demand for local food systems (Martinez et al., 2010). ${ }^{7}$ This consumer interest has multiple roots, including demand for product freshness, concerns over food safety or the environmental impacts of food production and distribution, and a desire to support local farmers and contribute to farm retention (Dukeshire, Garbes, Kennedy, Boudreau \& Osborne, 2011). Farm-direct marketing affords American consumers the opportunity to reconnect with the source of their food and agrarian culture.

\footnotetext{
${ }^{7}$ Martinez et al. (2010) note considerable variability in geography-based definitions of local. Vermont state law defines local as originating within 30 miles $(48 \mathrm{~km})$ of the point of product sale. The 2008 farm bill defines a local food product more liberally as one that is transported less than 400 miles $(644 \mathrm{~km})$ of its origin within only the state within which it is produced.
}

This concept is embodied in the USDA Know Your Farmer, Know Your Food campaign, which is designed to strengthen farmer-consumer connections and redevelop local and regional food systems.

Outdoor recreational activities were offered to the public by 12 percent of New Jersey agritourism farms and accounted for 16 percent of total agritourism revenue. As the amount of open space and natural landscapes dwindle, opportunities for farmers to offer fee-based or free hunting, fishing, birding, hiking, horseback riding, and other forms of passive or active outdoor recreational pursuits will continue to grow. Entertainment activities (common examples include hay mazes, hayrides, petting or looking zoos, and haunts) are often most synonymous with the public image of agritourism. Interestingly, fewer than 7 percent of agritourism farms engaged in entertainment activities, and this category of agritourism represented 9 percent of total revenue. Educational tourism, comprising farm tours for schoolchildren and the general public, winery tours, and to a lesser extent farm work experiences, was reported by seven percent of agritourism operators. These activities accounted for only three percent of state agritourism revenue. Larger tours (for instance, tours for schoolchildren designed to advance core curriculum standards) are generally fee-based. However, interviews with farmers reveal that some provide free farm tours to legislators or community members as a means to facilitate awareness and understanding of their operation and broader industry issues. Lastly, farm accommodations accounted for less than one percent of agritourism revenue in 
New Jersey and often comprise low or no-fee picnicking options or special event hosting (e.g., birthday parties). Overnight accommodation (e.g., bed and breakfast operations) is presently uncommon on New Jersey farms.

Evidence of Agritourism Operators' Nonmonetary Motivations and Expectations of Deferred Economic Gains?

Survey data revealed that 19 percent of farms engaged in agritourism during 2006 did not earn revenue from these activities. Large agritourism farms were more likely than small agritourism farms (32 percent versus 17 percent) to not earn revenue directly from agritourism activities $\left(\chi^{2}=\right.$ 3.01, $\mathrm{df}=1, p=0.083)$. These results raise the question, why would a business invest in the development of an activity that does not yield a positive return on investment? In some instances, agritourism may be perceived by farmers as a cost of doing business, something offered to satisfy customer expectations regarding the farm experience or connectivity to the farmer. However, past studies provide evidence that farmers are also motivated by nonpecuniary benefits that relate to their personal or familial circumstances (see, for example, McGehee \& Kim, 2004; Tew \& Barbieri, 2012). Farmers' interest in educating the nonfarm public about farming and agricultural issues is also well established as a motivation for farm-based tourism development (McGehee et al., 2007; Nickerson et al., 2001; Tew \& Barbieri, 2012). Past research is surprisingly silent, however, regarding the farmers' purpose for public education.

Educational interactions with customers may confer benefits to agritourism operators if, for example, they reduce conflicts with nonfarm neighbors, spur demand for local farm products, or strengthen public support for farm retention. Our survey found that 43 percent of New Jersey's farmland acreage (more than 300,000 acres or 121,000 ha) is associated with farms offering agritourism. ${ }^{8}$

\footnotetext{
${ }^{8}$ Recall that roughly one in five New Jersey farms offers agritourism. The much higher percentage of farmland operated by agritourism farms results from the fact that, on average, agritourism farms are significantly larger than non-
}

Agritourism farms therefore represent a significant exposure point for residents to learn about farming. They also allow nonfarmers to experience the multifunctionality of agricultural lands, a well established basis underlying public support for farm retention (Hellerstein et al., 2002; Kline \& Wichelns, 1994, 1996; Matthews, 2012). In fact, Adelaja, Colunga-Garcia, Gibson \& Graebert (2009) argue that the continuation of public funding for farmland preservation will be predicated largely upon the farm sector's ability to satisfy the plurality of interests that nonfarm residents maintain in farms and farmland. Whether agritourism effectively influences public support for farm retention, and the extent to which farmers' decisions to develop agritourism enterprises are motivated by goals associated with positive public relations, are interesting issues worthy of further research.

\section{Discussion}

Agritourism data from the census of agriculture suffer from limited scope and longitudinal perspective, but do document national growth in this sector. Agritourism development is particularly advanced in many northeastern states, where urbanization pressures have combined with macroeconomic and global factors over recent decades to steadily transform agricultural regions. Previous studies examining farmer motivations for engaging in agritourism conclude that both economic and non-economic factors motivate farmers to develop agritourism enterprises. Despite its growing popularity as an agricultural and rural community economic development strategy, the economic benefits of farmer participation in agritourism remain poorly quantified in the United States.

Economic motives are cited as a common reason farmers establish agritourism activities on their farms; however, some past research has reached the paradoxical conclusion that agritourism does not contribute substantially to farm revenue (see, for example, Busby \& Rendle, 2000; Oppermann, 1995). Tew and Barbieri's study of Missouri agritourism operations, for example, found that agritourism did not contribute to farm

agritourism farms; 150 acres (61 ha) and 71 acres (29 ha), respectively $(p=.045)$. 
income in 62 percent of cases examined; however, their definition excluded farm direct marketing as a subset of agritourism. Our study demonstrates that the economic contributions of agritourism to farm income are, in fact, quite variable and suggests several potential types of motivations for its development. For some farmers, agritourism is a primary source of farm income, while for others it supplements income from traditional production. Like Tew and Barbieri, our research also identified many farmers who do not earn income from their agritourism enterprises.

Our survey found that 51 percent of New Jersey agritourism farms earned at least half of their farm income from agritourism; 36 percent earned all of their income from agritourism. Farms earning a majority of their income from agritourism tend to be smaller in scale. This propensity is also evidenced by the fact that, nationally, small farms account for only 14 percent of the value of farm products sold by U.S. farmers, but 54 percent of agritourism receipts and 57 percent of farm direct marketing revenue (USDA-NASS, 2009). Small farms often find it challenging to compete effectively in increasingly global markets (Dougherty \& Green, 2011). They also tend to have less access to domestic wholesale marketing channels due to the consolidation of food retail activity among large firms that rely on 52-week supply chains. These factors, coupled with an inability to achieve the economies of scale necessary to offset high fixed costs (e.g., farmland and equipment acquisition) force many small farms to intensify production, find higher margin market channels, or develop alternative farm enterprises.

Any discussion of the economics of agritourism among "small farms" needs to be tempered by the reality that this farm typology encompasses several inherently different motives for farming. For example, 93 percent of New Jersey's farms are small farms, of which the USDA's Economic Research Service classifies twothirds (66 percent) as either retirement farms or residential/lifestyle farms (USDA-NASS, 2009). Census of Agriculture data further show that while these small-farm operators may look to farming as a supplement to household wages or retirement income, it rarely contributes significantly to total household income. Fewer than one-third of New Jersey's residential/lifestyle farms reported positive net cash flow from farming in 2007. In these cases, income may be a less consequential motive for farming than the enjoyment of a rural lifestyle. Revenue from agricultural production may only offset farm ownership and maintenance costs (for example, by generating agricultural revenue sufficient to qualify land for the tax benefits afforded by differential assessment). In contrast, small-farm operators for whom farming is a primary occupation (particularly those earning at least USD100,000 in farm revenue) are more driven by a profit motive.

The economic viability of small farms can therefore not be predicted based solely upon the magnitude of farm income generated, but rather by the extent to which farming income enables farm households to meet their varied financial objectives. Our study shows that agritourism is often a significant contributor to small-farm income and an important part of the equation for small-farm viability in New Jersey. This observation has important implications for individual farm operators, but also has broader social importance. While small farms are not a major contributor to total farm sales in the state (only about 16 percent), they control 61 percent of the state's farmland base. By contributing to the economic well-being of small farms, agritourism also contributes to the retention of substantial farmland resources and therefore the preservation of associated rural amenities.

Our study found that nearly four out of 10 large New Jersey farms engaged in some form of agritourism, but that they tended to be less reliant on agritourism as a percentage of total farm income. In fact, 92 percent earned less than half of their farm income from agritourism. More interesting is the fact that 32 percent of large agritourism farms did not earn income from agritourism activities. Reflecting the noted lack of uniformity in definitions, some past studies have defined agritourism in a manner that separates direct marketing activities (e.g., farm stands) from educationally or recreationally based activities. However, our economic impact assessment explicitly included 
on-farm direct marketing under the definition of agritourism. The finding that nearly one third of large agritourism farms (and 19 percent of all agritourism farms) do not earn agritourism revenue cannot therefore be explained in this manner.

As previously discussed, farmers recognize nonmonetary values of agritourism that serve as motivators for alternative enterprise development. Rather than immediate monetary gain, motivation for developing agritourism may be found in fulfillment of entrepreneurial goals, needs for social contact, rural lifestyle pursuits, and expansion of employment opportunities for farm family members. Accounts from New Jersey farmers reveal additional benefits from agritourism that may confer deferred economic benefits (Schilling et al., 2006). For example, as a pragmatic matter, the allowance of non-fee-based hunting may reduce farm expenses associated with culling wildlife or revenue losses from crop damage caused by wildlife. Past research also identifies public education as a common impetus behind agritourism development; however, as previously noted the intended purpose of such interactions remains unclear. Interviews with New Jersey farmers suggest that such interaction may result in benefits accruing at the individual farm and industry levels. At the farm level, inviting the public onto farms facilitates messaging about the quality, freshness, safety, and environmentally beneficial nature of local food sourcing. It also provides farmers with customer feedback and insight on local demand for various products needed to appropriately tailor marketing efforts.

More broadly, New Jersey agritourism operations (particularly larger operators) recognize the importance of garnering sociopolitical support for farming as an industry (Schilling et al., 2006). As a case in point, public support for farmland retention has been amply revealed through the passage of 11 funding referenda since the early 1960 s and the adoption over the past two decades of more than 330 local dedicated property taxes. State funding referenda in 2007 and 2009 were passed despite a climate of dramatic economic decline and fiscal austerity. Through the end of 2011, USD1.5 billion in public expenditures have supported fee simple and easement acquisition programs. Farmers attest that direct farmercustomer (voter) interaction is an effective tool for farming advocacy. ${ }^{9}$

The 2006 research also showed agritourism operators' interest in improving relations within their communities. Compounding the direct economic challenges that urbanization pressures impose upon the agricultural industry are the shifting sociopolitical and demographic conditions that often result in conflicts between farmers and new nonfarm neighbors. From a farmer's perspective, such conflicts may include trespass, vandalism, crop damage or theft, and livestock harassment. Nonfarm residents may object to undesirable realities of commercial farming, including odors, noise, dust, and application of fertilizers or other chemicals. Tensions between farmers and residential neighbors can rise to the level of legal conflict over perceived nuisances, or the passage of regulations that are less sensitive to the needs of the farming community. Often dubbed "right-tofarm" issues, these legal conflicts can be costly and emotionally disruptive to both parties.

The field of psychology offers the "contact hypothesis," which predicts that intergroup contact and communication may foster greater mutual acceptance and tolerance between groups constituting majority and minority social positions (Allport, 1954). Application of this theory in the agritourism context suggests that interactions between farmers and nonfarmers in a positive environment may contribute to a culture of understanding and mutual respect for the concerns of each party. That is, rather than relating as antagonists in a legal dispute or policy formation process, these actors can interact in a more mutually rewarding product/service provider-customer relationship. The extent to which farmer engagement in agritourism is consciously motivated by the objective of preempting or mitigating right-tofarm problems requires further investigation, as do the conditions influencing the efficacy of agri-

\footnotetext{
${ }^{9}$ In less formal interviews, farmers allowed that the public outcry over a 2008 gubernatorial proposal to eliminate the state department of agriculture was amplified as a result of direct interaction with farmers.
} 
tourism as a strategy for building positive community relations.

\section{Conclusions}

While not a panacea for the issue of American farm viability, there is converging statistical and anecdotal evidence that agritourism is an important opportunity for farmers, especially those operating at the urban fringe, to increase their viability. Agritourism may bolster the profitability of small family farms, and help communities retain the economic, employment, resource stewardship, and lifestyle benefits conferred by farms. Busby and Rendle (2000), however, note the absence of national studies examining the growth of agritourism. This paper was motivated by this gap in the literature and examines the economic significance of this emerging industry in a leading agritourism state.

Our research shows that the economic benefits of agritourism do not accrue equally across all farm size classes, suggesting that these activities fulfill different objectives or motivations within farm business models. Our study also reveals that a significant number of New Jersey farmers offer agritourism without charge. This observation highlights the need for further research on the nonmonetary motivations farmers have for developing agritourism enterprises. For example, whether farmers offer agritourism with the expectation that it effectuates good public relations or support for farm retention policy is a particularly intriguing research question. A companion inquiry is whether agritourism actually accomplishes these objectives.

As the amount of rural land dwindles in the nation's most urbanized regions, agritourism farms will become an increasingly important access point for nonfarm residents to enjoy rural amenities, recreation opportunities, and ecosystem values. Agritourism may become the de facto "face" of agriculture in many locales where farming has been displaced as a dominant part of the economic or physical landscape. Beyond protecting local capacity for food and fiber production, interest in retaining the social, environmental, and cultural benefits of farms is an important factor behind public commitments to farm retention. Properly developed agritourism enterprises can serve to reinforce this interest as they provide venues for educating the public about agricultural issues, fostering positive community relations, and exposing individuals to the multifunctional benefits of farms.

A farmer's success in reaching goals defined for an agritourism enterprise will depend upon many factors, including target market characteristics, the farm's natural or cultivated endowment of amenities, and the farmer's own entrepreneurial and business skills. Cooperative extension educators and other agricultural professionals can play an important support role as farmers transition to farm-based recreation, education, or marketing. A Northeast Sustainable Agriculture Research and Education (NESARE) professional development grant is supporting programming in the areas of marketing and risk management to help farmers meet the challenges arising when farmers shift from a production-wholesale business to one focused on retail, service, and hospitality.

Effective marketing, including product definition, pricing, and promotion, is an essential element of agritourism success. Yet marketing is commonly cited as being among the most significant business impediments reported by agritourism operators (Ryan, DeBord \& McClellan, 2006; Schilling, et al., 2006). Resources are needed to help farmers more clearly elucidate the amenities and services composing their agritourism enterprises. Agritourism is experiential, and the farm experience is multifaceted. It includes, for example, the friendliness and customer-service orientation of the farm proprietor and employees, the type of rural amenities and activities customers encounter, and the safety and visual appeal of the farm. To enhance the positive public engagement value of agritourism, there needs to be harmonization between the products farmers think they are providing, and those the customer is consuming.

A second area of programming supported by the NESARE grant is agritourism risk management. Farmers acknowledge the importance of ensuring farm visitor safety and managing legal liabilities associated with farm visitations (Schilling, et al., 2006). Farmers require guidance on strategies to reduce, transfer, and/or insure against the heigh- 
tened legal exposure that accompanies agritourists (Centner, 2009). Cooperative extension and other agricultural service providers can provide valuable insights on conducting farm safety inspections, planning for on-farm emergencies, and adopting best practices for specific agritourism activities. Resources on enterprise budgeting and financial analysis of agritourism alternatives can similarly help farmers manage financial risk.

\section{Acknowledgments}

Funding for this project was provided by the New Jersey Department of Agriculture, Rutgers Cooperative Extension, and Rutgers Food Policy Institute. The authors thank the New Jersey Field Office of the National Agricultural Statistics Service staff and Director Troy Joshua for partnering on the implementation of this project. Comments on an earlier draft provided by the editor and three anonymous reviewers are greatly appreciated.

\section{References}

Abler, D. (2004). Multifunctionality, agricultural policy, and environmental policy. Agricultural and Resource Economics Review, 33(1), 8-17.

Adelaja, A., Colunga-Garcia, M., Gibson, M., \& Graebert, M. (2009). Emerging public preferences and the sustainability of farmland preservation. In S. Goetz and F. Brouwer (Eds.), New perspectives on agrienvironmental policies: A multidisciplinary and transatlantic approach (pp. 260-282). New York: Routledge Publishing.

Adelaja, A., Hailu, Y., Wyckoff, M., \& Bailey, E. (2008, May). How states grow: Old vs new economy.

Presentation at the 2008 World Congress on National Accounts and Economic Performance Measure for Nations, Washington, D.C.

Allport, G. (1954). The nature of prejudice. Cambridge, Massachusetts: Perseus Books.

Alonso, A. (2010). To what extent do farmers educate consumers? A case study from Alabama. Journal of Agricultural and Food Information, 11(4), 307-321. http://dx.doi.org/10.1080/10496505.2010.511975

Barbieri, C., \& Mahoney, E. (2009). Why is diversification an attractive farm adjustment strategy? Insights from Texas farmers and ranchers.
Journal of Rural Studies, 25(1), 58-66. http://dx.doi.org/10.1016/j.jrurstud.2008.06.001

Barbieri, C., Mahoney, E. \& Butler, L. (2008). Understanding the nature and extent of farm and ranch diversification in North America. Rural Sociology, 73(2), 205-229.

Barbieri, C. \& Mshenga, P. (2008). The role of the firm and owner characteristics on the performance of agritourism farms. Sociologia Ruralis, 48(2), 167-183. http://dx.doi.org/10.1111/j.1467-9523.2008. 00450.x

Barry, J., \& Hellerstein, D. (2004). Farm recreation. In H. K. Cordell (Ed.), Outdoor recreation in $21^{\text {st }}$ century America: A report to the nation: The national survey and recreation and the environment (pp. 149-167). State College, Pennsylvania: Venture Publishing.

Batie, S. (2003). The multifunctional attributes of northeastern agriculture: A research agenda. Agricultural and Resource Economics Review, 32(1), 1-8.

Bergstrom, J., \& Ready, R. (2011). What have we learned from over 20 years of farmland amenity valuation research in North America? Applied Economic Perspectives and Policy, 31(1), 21-49. http://dx.doi.org/10.1111/j.1467-9353.2008. 01424.x

Berry, D. (1978). Effects of suburbanization on agricultural activities. Growth and Change, 9(3), 28. http://dx.doi.org/10.1111/j.1468-2257.1978. tb01024.x

Busby, G., \& Rendle, S. (2000). The transition from tourism on farms to farm tourism. Tourism Management, 21(6), 635-642. http://dx.doi.org/ 10.1016/S0261-5177(00)00011-X

Carpio, A., Wohlgenant, M., \& Boonsaeng, T. (2008). The demand for agritourism in the United States. Journal of Agricultural and Resource Economics, 33(2), 254-269.

Centner, T. (2009). New state liability exceptions for agritourism activities and the use of liability releases. Agriculture and Human Values, 27(2), 189-198. http://dx.doi.org/10.1007/s10460-009-9220-y

Che, D., Veeck, A., \& Veeck, G. (2005). Sustaining production and strengthening the agritourism product: Linkages among Michigan agritourism destinations. Agriculture and Human Values, 22(2), 225-234. http://dx.doi.org/10.1007/s10460-004$\underline{8282-0}$ 
Das, B., \& Rainey, D. (2010). Agritourism in the Arkansas delta byways: Assessing the economic impacts. International Journal of Tourism Research, 12(3), 265-280. http://dx.doi.org/10.1002/jtr.752

Dillman, D. (2007). Mail and Internet surveys: The tailored design method (2nd ed.). New York: Wiley.

Dimitri, C., Effland, A., \& Conklin, N. (2005). The 20th century transformation of U.S. agriculture and farm policy (ERS Information Bulletin No. 3). Washington, D.C.: United States Department of Agriculture, Economic Research Service Economic.

Dougherty, M., \& Green, G. (2011). Local food tourism networks and word of mouth (Article 2FEA5). Journal of Extension, 49(2). Retrieved from http://www.joe.org

Dukeshire, S., Garbes, R., Kennedy, C., Boudreau, A., \& Osborne, T. (2011). Beliefs, attitudes, and propensity to buy locally produced food. Journal of Agriculture, Food Systems, and Community Development, 1(3), 19-29. http://dx.doi.org/10.5304/jafscd.2011.013.008

Fleischer, A., \& Tchetchik, A. (2005). Does rural tourism benefit from agriculture? Tourism Management, 26( 4), 493-501. http://dx.doi.org/10.1016/j.tourman.2003.10.003

Hjalager, A.-M. (1996). Agricultural diversification into tourism: Evidence of a European Community development programme. Tourism Management, 17(2), 103-111. http://dx.doi.org/10.1016/02615177(95)00113-1

Hellerstein, D., Nickerson, C., Cooper, J., Feather, P., Gadsby, D., Mullarkey, D., Tegene, A., \& Barnard, C. (2002). Farmland protection: The role of public preferences for rural amenities (Agricultural Economic Report No. AER815). Washington, D.C.: United States Department of Agriculture, Economic Research Service.

Hill, R., \& Busby, G. (2002). An inspector calls: Farm accommodation providers' attitudes to quality assurance schemes in the county of Devon. International Journal of Tourism Research, 4(6), 459-478. http://dx.doi.org/10.1002/jtr.400

Ilbery, B., Bowler, I., Clark, G., Crockett, A., \& Shaw, A. (1998). Farm-based tourism as an alternative farm enterprise: A case study from northern Pennines, England. Regional Studies, 32(4), 355-364.
Kline, J., \& Wichelns, D. (1994). Using referendum data to characterize public support for purchasing development rights to farmland. Land Economics, 70(2), 223-233. http://dx.doi.org/10.2307/3146324

Kline, J., \& Wichelns, D. (1996). Public preferences regarding the goals of farmland preservation programs. Land Economics, 72(4), 538-549. http://dx.doi.org/10.2307/3146914

Kortright, R., \& Wakefield, S. (2011). Edible backyards: A qualitative study of household food growing and its contributions to food security. Agriculture and Human Values, 28(1), 39-53. http://dx.doi.org/10.1007/s10460-009-9254-1

Lindsey, G., \& Knaap, G. (1999). Willingness to pay for urban greenway projects. Journal of the American Planning Association, 65(3), 297-313. http://dx.doi.org/10.1080/01944369908976059

Lopez, R., Adelaja, A., \& Andrews, M. (1988). The effects of suburbanization on agriculture. American Journal of Agricultural Economics, 70(2), 346-358. http://dx.doi.org/10.2307/1242075

Martinez, S., Hand, M., Da Pra, M., Pollack, S., Ralston, K., Smith, T., Vogel, S., Clark, S., Lohr, L., Low, S., \& Newman, C. (2010). Local food systems: Concepts, impacts, and issues (ERS Research Report No. 97). Washington, D.C.: United States Department of Agriculture, Economic Research Service.

Matthews, L. (2012). From the ground up: Assessing consumer preferences for multifunctional agriculture. Journal of Agriculture, Food Systems, and Community Development, 2(2), 51-70. http://dx.doi.org/10.5304/jafscd.2012.022.011

McGehee, N. (2007). An agritourism systems model: A Weberian perspective. Journal of Sustainable Tourism, 15(2), 111-124. http://dx.doi.org/10.2167/jost634.0

McGehee, N., \& Kim, K. (2004). Motivation for agritourism entrepreneurship. Journal of Travel Research, 43(2), 161-170. http://dx.doi.org/10.1177/0047287504268245

McGehee, N., Kim, K., \& Jennings, G. (2007). Gender and motivation for agri-tourism entrepreneurship. Tourism Management, 28(1), 280-289. http://dx.doi.org/10.1016/j.tourman.2005.12.022 
Mitchell, M., \& Turner, G. (2010). Agri-tainment: A new crop for farmers. Journal of Food Products Marketing, 16(4), 373-385. http://dx.doi.org/10.1080/10454446.2010.509238

New England Agricultural Statistics Service. (2004). Vermont agri-tourism 2002. Concord, New Hampshire. Retrieved from http://www.nass. usda.gov/Statistics by State/New England

Nickerson, N., Black, R., \& McCool, S. (2001). Agritourism: Motivations behind farm/ranch business diversification. Journal of Travel Research, 40(1), 19-26. http://dx.doi.org/10.1177/004728750104000104

Nilsson, P. (2002). Staying on farms: An ideological background. Annals of Tourism Research, 29(1), 7-24.

Ollenberg, C., \& Buckley, R. (2007). Stated economic and social motivations of farm tourism operators. Journal of Travel Research, 45(4), 444-452. http://dx.doi.org/10.1177/0047287507299574

Oppermann, M. (1995). Holidays on the farm: A case study of German hosts and guests. Journal of Travel Research, 34(1), 63-67. http://dx.doi.org/10.1177/004728759503400108

Phillip, S., Hunter, C., \& Blackstock, K. (2010). A typology for defining agritourism. Tourism Management, 31(6), 754-758. http://dx.doi.org/10.1016/j.tourman.2009.08.001 Ryan, S., DeBord, K., \& McClellan, K. (2006). Agritourism in Pennsylvania: An industry assessment. Harrisburg, Pennsylvania: Center for Rural Pennsylvania. Retrieved from http://www.rural.palegislature.us

Ryan, R., \& Walker, J. (2004). Protecting and managing private farmland and public greenways in the urban fringe. Landscape and Urban Planning, 68(2/3), 183198. http://dx.doi.org/10.1016/S01692046(03)00165-8
Schilling, B. (2009). Local planning for agriculture: A new charge to the planning profession (Unpublished doctoral dissertation). Rutgers, the State University of New Jersey, New Brunswick, New Jersey.

Schilling, B., Marxen, L., Heinrich, H., \& Brooks, F. (2006). The opportunity for agritourism industry development in New Jersey. New Brunswick, New Jersey: Rutgers, the State University of New Jersey, Food Policy Institute. Retrieved from http:// foodpolicy.rutgers.edu

Schilling, B., Sullivan, K., \& Marxen, L. (2007). The economic impact of agritourism in New Jersey: A 2006 assessment. New Brunswick, New Jersey: Rutgers, the State University of New Jersey, Food Policy Institute. Retrieved from http:// foodpolicy.rutgers.edu

Sharpley, R., \& Vass, A. (2006). Tourism, farming and diversification: An attitudinal study. Tourism Management, 27(5), 1040-1052. http://dx.doi.org/10.1016/i.tourman.2005.10.025

Tew, C., \& Barbieri, C. (2012). The perceived benefits of agritourism: The provider's perspective. Tourism Management, 33(1), 215-224. http://dx.doi.org/10.1016/j.tourman.2011.02.005

United States Department of Agriculture, National Agricultural Statistics Service [USDA-NASS]. (2009). 2007 Census of Agriculture, State-level data. Retrieved May 2011 from http://www.agcensus.usda.gov/Publications/2007 /Full Report/Volume 1, Chapter 1 State Level/ New Jersey/

Veeck, G., Che, D., \& Veeck, A. (2006). America's changing farmscape: A study of agricultural tourism in Michigan. The Professional Geographer, 58(3), 235248. http://dx.doi.org/10.1111/j.1467-9272.2006. 00565.x 